HANNA GRZESZCZUK-BRENDEL

Faculty of Architecture

Poznan University of Technology

\title{
Rhetoric of the image of architecture
}

\begin{abstract}
Aвstract. Grzeszczuk-Brendel Hanna, Rhetoric of the image of architecture. "Images" vol. XXII, no. 31. Poznań 2017. Adam Mickiewicz University Press. Pp. 29-37. ISSN 1731-450X. DOI 10.14746/i.2017.31.04.

Based on the example of one of the newsreels of the Polish Film Chronicle of 1965, we have researched the issue of the usability of rhetorical figures for the analysis of the image of architecture recorded in film and its relations with the verbal rhetoric of narration as well as the pictorial rhetoric, which makes up the message of a different nature. By this we have attempted to decode the lifestyle model presented in the film and propagated by its manner of description of architecture with the use of rhetorical figures and also to decode the role and meaning of the architectural forms, which were engaged in the creation of the message of the film image. Combining the rhetorical analysis with an interpretation of the architectural forms has enabled us to identify the persuasive nature of the message of the chronicle material included in the documentary film.
\end{abstract}

Keywords: Polska Kronika Filmowa [Polish Film Chronicle], rhetorical devices, interpretation of architecture, architectural contrasts, modernism

The application of a research on rhetorics means the focus of the researcher is on the persuasive nature of the image, in this case the image of architecture presented in the Polish documentaries of the 1960s. Even though rhetoric as such dates back to Ancient Greece, visual rhetoric is a relatively new concept, developed in the 1970s, occurring alongside the 'pictorial turn' phenomenon in culture and alongside a variety of interpretations of the expanding iconic sphere. Increased interest in the rhetoric of the image, and more precisely, in the message of the visual image, derives from structuralism and mainly from the works of Roland Barthes,[1] or, for instance, Treni R. Walker.[2] On the other hand, the extending of the definition of a text to cover all and any cultural works has contributed to the fact that architecture has been interpreted, for example by Umberto Eco. in linguistic terms, which means that if we talk about the image of architecture, then we talk about the image of the image (picture of the picture), the text about the text.

In accordance with our common knowledge about the times of the Polish People's Republic, we could expect that a documentary of the times would not present an account of the real world but that it would rather be some kind of propaganda message with its inherent rhetoric. However, the purpose of this article is not only to verify whether the rhetorical analysis of the image of architecture would enable us to

[1] R. Barthes, Retoryka obrazu, in: Ut pictura poesis, ed. M. Skwara, S. Wysłouch, Gdańsk 2006, pp. 139-158.
Images vol. XXII/no. 31 Special Issue Poznań 2017 ISSN $1731-450 x$ 
identify the rhetorical figures introduced by architecture into the film image, but also to find out to the extent to which such an identification is possible. The possibility of identifying the model of lifestyle proposed by these images, the way of describing architecture via the rhetorical figures applied and also the role of architectural forms engaged in the creation of this model seem to be equally important here. A search for the rhetorical figures in the chosen narrative is an attempt to "find out what, in a given situation, is convincing to the recipients, and why the rhetorical analyses tell us so much about the conventions and stereotypes predetermining our communication".[3] Focusing on the pictorial representation of architecture, I treat the verbal layer of the films being discussed as an accompanying phenomenon and do not subject it to an in-depth analysis.

The analysis is based on a documentary from the Polska Kronika Filmowa $(3 / 65 \mathrm{~B})$ made by Olgierd Budrewicz in the Documentary and Feature Film Studio in 1965, and entitled Jej Jubileuszowa Mość Warszawa [Her Majesty, Warsaw, the Jubilarian], in commemoration of the 2oth anniversary of the liberation of Poland's capital city[4]. Its narration is typical of the times, however, the chronicle itself diverges from the most commonly applied layout of a number of different themes. This documentary is entirely devoted to a single theme, which makes it all the more suitable for an analysis of its structure and the rhetorical figures applied.

The film complies with the classical unity of time, place and action, showing, over the course of one day, the achievements accomplished in Warsaw in the 20 years since the end of World War II.

The dawn-to-dusk framework creates a clear framing for the composition, but above all clear meaning. The cohesion of narrative is reinforced with the convergence of words and images, both with respect to the contents and the manner in which the pictorial narrative develops. Between the camera shots from the bird's eye view, which form a certain action framing device, the film uses almost all types of shot available: from the from long shots to extreme close-ups.

The variety of the film settings is connected with the variable but mutually cohesive rhythm of the verbal and pictorial narrative, for example, the accelerated oral commentary corresponds to a quick change of the frames, and the backing track changes accordingly. This changeability not only gives an organizing principle to the montage but also conveys the meaning as an element of the persuasive message to the recipient. Alternation between slow and accelerating images and a similar rhythm of verbal narration are applied all through the film, which enables the director to capture the changing nature of the city and the diversity of its inhabitants. The numbers which accompany the

[3] A. Kampka, Retoryka wizualna. Pytania i perspektywy, "Forum Artis Rhetoricae" 2011, no. 1.

[4] The documentary is available at: <https://www. youtube.com/watch?v=EOsoaMKBBgI $>$. Digits which appear in brackets at the descriptions of the selected fragments of the film denote the timing of the fragment as per the timing appearing at the bottom of the frame of the chronicle. 
camera shots suggest an objectivity or genuineness in the narration, which is further underlined by "live" recorded images.

The rationality of the words is in some parts interspersed with pathos, whereas the sublimity is juxtaposed with confessions revealing some of the problems of the city and its inhabitants, - which makes this narrative close to the life experience of a typical Warsaw dweller, and which does not obstruct the message of success propagated by the film.

The narrative is initially of a ceremonial nature, mainly due to the application of the apostrophe in the verbal layer: both in the title headline and in the congratulations to the jubilarian ("one thousand years - let him live!"), which personifies the capital city.

All this is accompanied by a panoramic, bird's eye view of Warsaw, anthropopathetically proud of its own achievements, whereas the harmony between the image and the verbal commentary makes each layer of the film more and more important, and the application of epitasis is fully grounded here. The panoramic view is the pictorial equivalent of the verbal pathos ("heroic city", "Warsaw is a myth and a legend"); the view from the bird's eye view focuses on the architecture of the city centre, underlines the density of development, the grandeur of MDM squares and the reconstructed Old Town. However, it also includes the tower blocks of the new housing estates.

Shortly after the beginning of the film this all-embracing, slowly moving, panoramic view is, juxtaposed with close-up shots of the details, which is a stylistic device used throughout the film, underlying the change of mood or the appearance of a new motif. Such transitions draw the viewer's attention to the changes between grandeur and daily life, displayed in the contrasts used in order to complete the entire cycle e.g. the picture of official edifices of the state administration, production halls as well as the housing estates, but also shown via a change of perspective and slightly jocular comments ("Warsaw industrial plants contribute significantly to increasing water, electricity, water and gas consumption per capita"). The motif of a busy street (often with no text in the background) is the most frequently used interlude. Later in the narrative it performs the function of an anaphora, which, via subsequent repetitions, gives rhythm to the film and enables the viewer to identify with the image being presented. Close-up shots of the passers-by in a crowded street apparently break the pomposity and enable us to identify respective individuals. The applied synekdoche is to underline the sense of unity of the passers-by walking along the streets of Warsaw. Thus, it creates this sense of identification with other inhabitants, denies their anonymous status and changes the crowd into a community.

Architecture appears in many scenes, it is shown as the background of events or it is shown in close-up shots as their part, thus the architecture is woven into the fabric of human life, even if it is not explicitly expressed. However, in several frames architecture makes 
up the foreground, dominating this aspect of the narrative. It is worth mentioning that the rhythm of recurring motifs is only applied to two aspects, namely the people and the buildings.

After breaking through the busy street, the camera slowly moves from one governmental building to another, showing them as grand edifices in the foreground. This suggests a certain distance to the ordinaryinhabitant, at the same time, the slowing down of the pictorial narrative harmonizes with the style of the edifices: the two rhetorical devices remind us of different time proportions, the time when the decisions of party leaders and members of the government were taken in a wider perspective. (2.10-2.22). This interpretation seems to be reaffirmed with the recurring pictorial brachylogy, which, in certain fragments of the narration, accelerates the story.

Focusing on smaller and smaller fragments and sections when presenting respective institutions is related to this brachylogy: once again we step down to the level of daily life and work performed by Varsovians for the good of the entire country. Here, the architecture serves as metonymy - a substitute for the man (2.18-2.36), whereas the individual is merely a component of the statistical data quoted in the commentary. What's interesting here is that the industrial workers are presented at their workstations and the close-up shots show not only their faces but also the details of their work. Students are also presented in close-up (6.56).

The transition from a general to a detailed view is particularly frequently applied in the images of the architecture of housing estates. The focus on the swift, intensified rhythm of windows and balconies is to present the mass scale of residential construction industry, whereas the modern form of the buildings is to symbolise modernity, not only in architecture - it is to play the role of an allegory for the entire society of the Polish People's Republic. Such an interpretation of the architecture in the film can be supported with the counter-pointed juxtaposition of two frames, falling one after the other: an old, horsedrawn cab and a fragment of a modern tower block, embroidered with loggias (5.02-5.03). The views that follow, either the views of the entire buildings or their fragments or the views of the surrounding greenery, seem to indicate that the modern, residential blocks encompass the most wanted features of a modern flat.

It is an interesting fact that the residential architecture is photographed in a similar way to the passers-by in the street: in close-up shots and in accelerated motion. The window frames, rows of loggias and protruding balconies which populate the film frames serve as an equivalent of the synekdoche: they bring to mind the idea of a flat for everyone (the accompanying commentary: for every second Warsaw dweller living in a new flat).

As home is a mainly private zone, in subsequent frames we enter a flat, to be precise its most intimate space, namely the bathroom, where two girls are taking a bath (5.37-5.40). This is then juxtaposed with the 
frame showing small, wooden houses, thus creating a sharp contrast between modern, sanitised housing estates and relics of the old times, which were more frequently seen as the things of the bygone past. Such relics were the huts and dilapidated tenement houses, photographed from the backyard perspective to evoke the cramped and dark 'closed yards' typical of a 19th-century capitalist town (5.44-5.48). The message here is underlined by the frames that directly follow or precede this image and focus on small children (5.56). It is worth noting that the people resented in the chronicle were mainly young people, which clearly refers to a popular slogan in the Polish People's Republic - "the youth is the future of the nation".

Another architectural motif, which draws the attention of the viewers, is the Palace of Culture and Science, although the waythis building is presented may seem astonishing. We do not see the entire silhouette of the edifice, which was intended to be the symbol of socialist Warsaw, but we first see its interior, and more precisely its modern lift, which metaphorically enables the viewer's eye to move along the façade up to the top of the building spire. (8.40; 8.48). The close-up shot is a slightly different application of an anaphora, this time not as a recurring motif but as a recurring stylistic device, namely a zoom-in.

Explanations can be contradictory. The Palace of Culture and Science is a well-known building, it does not have to be shown in its entirety, it can be easily identified on the basis of the details, via a synekdoche. We could, however, also suspect that the architectural form of the building might have been intentionally ignored, as it would, without doubt, have been associated with the social realism period, which in the 1960 s was viewed as a period of dictatorship. The smooth presentation of the details, rather than the entire picture, also enabled the film director to hide the outdated "innovative nature" of the Palace of Culture, expressed in the building form, which at the time the documentary was made, was perceived as old-fashioned; the landmark of the future was at the time seen in the building of 'Centralny Dom Towarowy' Central Department Store/CDT (9.58), which makes for another architectural interlude in the film.

Paradoxically, the CDT was erected at more or less the same time as the Palace of Culture: it was designed in 1947-1948 by Zbigniew Ihnatowicz and Jerzy Romański and commissioned in 1951, after the introduction of the doctrine of social realism (1949), hence it was therefore much criticised by that time.

In the story of the jubilee of Warsaw related in the chronicle, the CDT building, together with the preceding view of the Supersam supermarket (9.44), is deemed to be yet another symbol of modernity and the astonishment of a female customer (10.07-10.11) simply transforms it into a temple of commerce, filled with all types of commodities available to the city's inhabotants. It seems, however, that not only the plentifulness of commodities raises such admiration but also the 
architecture, at which the woman in a headscarf, typical of peasant women, looks with great admiration. Retail sales presented via the pictures of the stores operating at the housing estates, Supersam and CDT, just like the residential construction industry, are presented in an unambiguously modern style.

Considering the fact that the deficiencies of goods and flats were the most acute for the inhabitants, displaying the modernity of this type of architecture (residential architecture and the architecture of the department stores and other retail sales buildings) must have been a conscious device not only to convince the viewers of the story of success but also to conceal current facts.

The last time when architecture is in the foreground is in the sequences showing fragments of the Old Town (13.06->); here tradition strongly intertwines with the past, which was reconstructed and thus updated after the destruction of the war. Thereafter, the image slowly zooms out, to show the panoramic, bird's eye view again, thus forming the framework smoothly closing the story.

These frames which bring the film to a close, where the image zoomed out is linked with dusk falling over the illuminating street lamps, become an opportunity to remind viewers of the anniversary of regaining independence. The commentary tells us to view the night as the synonym of rest after a busy day in the city, which has been reconstructed from the ruins and contradicts the total annihilation to which it was supposed to be doomed in the and World War.

The analysis of the manner of narration enables us to notice the cohesion of the individual rhetorical figures, applied both in the verbal and pictorial layers, which can be seen in their mutual supplementation and reinforcement via redundancy.

Transposing the rhetorical devices into an analysis of architecture is easier compared to the analysis of the text, as identifying the meaning of architecture has a long tradition, greatly exceeding that of the semiotic perception of architecture as a cultural text. [5] Interpreting architecture as a carrier of form and meaning shall in this case only mean the use of other rhetorical devices, which in their pure form are rarely used by art historians.

However, let's come back to the film under discussion. In the film we are not presented with architecture 'as such' but with an image of architecture; an image, which is not to speak of its designatum but which is to become a designatum of a higher level, here being the film image. Here, references to the classical history of art and the analysis of the style of the buildings presented prove quite useful, thus, the function of architecture presented in the film can be explained in a broader sense.

The images of the Old Town, emphasised at the beginning and at the end of the chronicle not only remind the viewers of the recon-

[5] As regards the issues of rhetoric, this tradition is presented among others e.g. in A. Kampka, op.cit. 
struction after the destruction of the war but, first and foremost, define tradition, which was in the time of the Polish People's Republic referred to, accepted and adjusted, and, at the same time, refined. It is not a coincidence that in the final sequences, the monument of Kiliński, the folk hero, or even the (inferred) 'proletarian' hero, appears. After its reconstruction, the Old Town, which before the and World War had been a rather dilapidated part of Warsaw, became a symbol of the accepted past, which allowed for a sense of continuity, reflected in the doctrine of conservation propagated by Jan Zachwatowicz. "He thought that in the event of exceptional destruction, the reconstruction, with society's full consent, in compliance with the classical designs [...] was fully grounded. At the same time, the reconstruction of the city confirmed the legitimacy of the new government to maintain power".[6]

The offices of the government authorities shown in the background of the full film setting represent the style of modernised classicism, which was so much popular in the inter-war period and used for official buildings, but they also feature the neo-classical architecture of the turn of the 18th and 19th centuries. The forms originating from classicism were, however, accepted in the socialist period, and above all, in the period of social realism. In this context, a different way of presenting the Sejm building [one of the houses of the Polish Parliament], Belweder palace or the Palace of Culture is meaningful. In the former case, the distance obtained in the full frame, with the pure form of edifices in the background, refers to the interpretation of classicism as the universal style, and the style which, irrespective of the current political context, brings together its inherent values since the Ancient times, namely: democracy, prestige, harmony. The Palace of Culture, which we fail to see in its entirety and which is presented via such details as the lift, is rendered as merely an edifice of daily use, as such free of any connotations with Stalinism.

Here the architectural tradition is referred to in a different manner, serving as the contrast underlining the assets of the new construction industry. This role is played by the residential blocks contrasted with the images of small suburban, wooden huts, with no such facilities as the bathroom. All this is emphasised by the commentary and biased selection of the images of old tenement houses with plaster holes and dark, enclosed yards, in turn contrasted with open plan greenery of the housing estates. This contrast was even more explicit at the time of recording of the film because the vast majority of people lived in such dilapidated houses, thus in conditions which the more and more strict sanitary requirements would have deemed substandard .

Against the background of the styles and types of architecture that are differently valued but which all represent the past, the new construction is unambiguously assessed positively. Not only is the new

[6] G. Klause, Wybrane problemy ochrony zabytków poczatku XX wieku i odbudowa Poznania po II wojnie światowej, in: Architektura i urbanistyka Poznania w XX wieku, ed. T. Jakimowicz, Poznań 2005, p. 284. 
stylistic quality related to this, but so are the symbols of the new life. It's worth referring here to the features of good architecture propagated by the inter-war avant-garde, architecture that was to ensure the three aspects the new man was to enjoy: air, sun and greenery. These enjoyable aspects are implemented in the new modern architecture of the housing estates and department stores or other retail facilities, they are also visible in the glimpses of the modern factory buildings.

This unambiguously positive image of modern architecture shapes not only the surroundings but also the lifestyle of its dwellers. The rhetorical pictorial figures applied in the film suggest this interpretation, and at the same time this interpretation is convergent with the rhetoric of the inter-war avant-garde, which intended to create both new architecture and also the new man and the new society. The architecture treated within modernism as the metaphor of the new life/man/society shows that within the applied verbal and pictorial rhetoric the image of architecture is a metaphor of a metaphor. This accumulation of rhetorical devices reinforces the narrative focused on the lifestyle created by Warsaw's inhabitants in the 20-year period following the city's liberation, and who, in turn, represent the inhabitants of the entire country.

As Le Corbusier wrote: "Architecture or revolution. Revolution can be avoided". [7] For the authorities of the Polish People's Republic the revolution had taken place and modern architecture was to convince the people about this fact, promising them that the housing estate would be part of the future, with flats available to everyone, if not just instantly, then anyway feasible to be achieved with the combined efforts of the entire nation.'

Architecture also plays an important role in the creation of an image of the future in another, different way: the structure of the film constitues a cycle, suggesting the cyclical nature of time, a repeatable rhythm of the day and night, whereas the modernity of architecture introduces linear time, which moves towards the future. Even though the word 'socialism' does not appear in the narration, it is inherently implied therein: in the Polish People's Republic modernity equalled socialism, and as per this assumption it was the socialist modernity.

This documentary, an account of Warsaw's achievements in the 20-year period, is also a forecast of the future and creates the images of this, which is confirmed by other pictorial epithets related to innovation, youthfulness, modernity, progress, both in respect to the architecture and the people. New people live in new houses and their work contributes to the modernity of the city. Architecture and people create the city and are in fact one and the same city.

However, it is mainly the images of architecture that have this persuasive power, which can confirm that socialism should be deemed as the road to progress and which shows the material evidence that 
would let viewers feel proud of the previous achievements and that would serve as the embodiment of welfare, promising the onset of general happiness. For that reason the images presented in Jej Jubileuszowa Mość Warszawa [Her Majesty, Warsaw, the Jubilarian] continuously allude to the ideas or concepts, using positive connotations to different forms, styles and types. The architecture that is presented not only reinforces the message of the film but also reveals its persuasive nature, disclosing the propaganda masked in the form of a documentary. To discover this, it is useful to refer to the rhetoric, including the visual rhetoric, as well as to the typical competences of the art historian.

Barthes R., Retoryka obrazu, in: Ut pictura poesis, ed. M. Skwara, S. Wysłouch, Gdańsk 2006

Budrewicz O., Jej Jubileuszowa Mość Warszawa, 1965, <https://www.youtube.com/ watch?v=EOsoaMKBBgI $>$ [accessed on: 10.10.2015]

Eco U., Nieobecna struktura, Warszawa 1996

Gösel P., Leuthäuser G., Architektura XX wieku, Warszawa 2007

Hendrykowski M., Słownik terminów filmowych, Poznań 1994

Kampka A., Retoryka wizualna. Pytania i perspektywy, "Forum Artis Rhetoricae" 2011, no. 1

Klause G., Wybrane problemy ochrony zabytków początku XX wieku i odbudowa Poznania po II wojnie światowej, in: Architektura i urbanistyka Poznania w XX wieku, red. T. Jakimowicz, Poznań 2005

Le Corbusier, W stronę architektury, Warszawa 2012

Mitchell W.J.T., Zwrot piktorialny, "Kultura Popularna" 2009, no. 1(23)

Walker T.R., Historical literacy: Reading history through film, "The Social Studies" 2006, no. 97(1)

Zachwatowicz J., O polskiej szkole odbudowy i konserwacji zabytków, Warszawa 1981

Zachwatowicz J., Program i zasady Konserwacji Zabytków, "Biuletyn Historii Sztuki i Kultury" 1946, no. 1-2 